\title{
Uprzęże w indywidualnym sprzęcie chroniącym przed upadkiem z wysokości
}

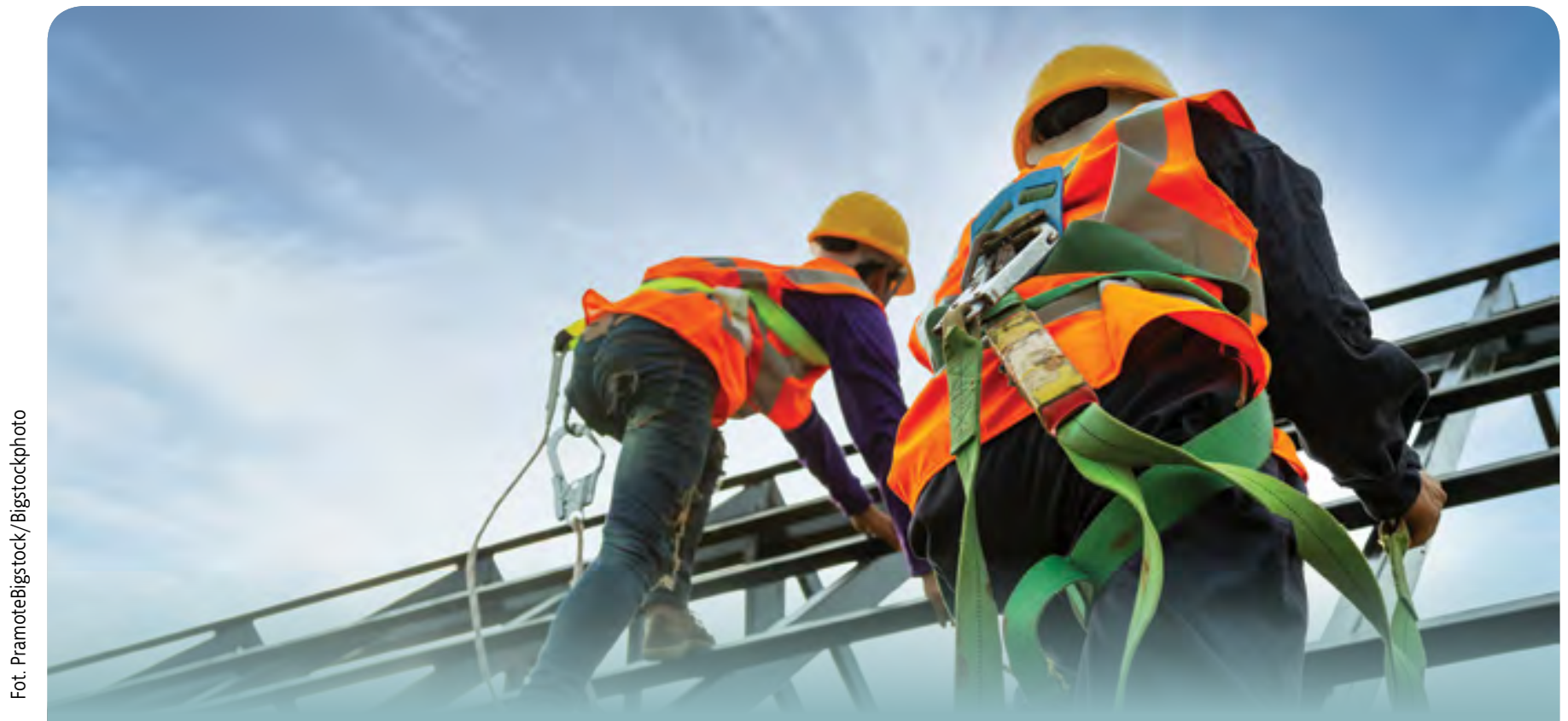

Integralnym elementem wszystkich indywidualnych systemów chroniących przed upadkiem z wysokości, stosowanych zarówno w warunkach przemysłowych, jak i podczas uprawiania sportu oraz rekreacji, jest uprząż, którą zakłada na siebie użytkownik sprzętu. Do najważniejszych zadań uprzęży, w zależności od jej rodzaju, należą: podtrzymanie ciała człowieka podczas i po powstrzymaniu spadania z wysokości, umożliwienie zajęcia pozycji podpartej, podtrzymanie ciała użytkownika w zawieszeniu podczas wykonywania pracy techniką dostępu linowego (rope access) oraz uniemożliwienie wejścia w strefę zagrożoną rozpoczęciem spadania. Przeznaczenie uprzęży jest ściśle związane z jej konstrukcją. W artykule zaprezentowano podstawowe konstrukcje oraz stosowane w nich materiały. Przedstawiono najważniejsze wymagania stawiane uprzężom oraz określono zasady ich doboru w zależności od warunków panujących na stanowisku pracy, w tym występujących zagrożeń i wykonywanych czynności. W artykule podano też podstawowe zasady użytkowania, przeglądów i oceny stanu technicznego uprzęży (ze szczególnym uwzględnieniem czynników powodujących ich degradację) oraz warunki ich wycofania z użytkowania. Bazując na badaniach prowadzonych w CIOP-PIB, zaprezentowano problematykę zagrożeń ze strony uprzęży dla człowieka w stanie zawieszenia.

Słowa kluczowe: upadek z wysokości, uprząż, szelki bezpieczeństwa, pas do ustalania pozycji

Harnesses in personal equipment protecting against falls from a height

An integral element of all personal fall protection systems, used both in industrial conditions and during sports and recreation, is the harness that the user of the equipment puts on. The most important tasks of the harness, depending on its type, include: supporting the human body during and after a fall arrest, enabling a supported position, supporting the user's body suspended during work with the rope access technique and preventing entry into the zone at risk of falling. The purpose of the harness is closely related to its construction. The article presents the basic structures and the materials used in them. The most important requirements for harnesses were presented and the rules for their selection depending on the conditions at the workplace, including the hazards and activities performed, were defined. The article also presents the basic principles of use, inspections and evaluation of the technical condition of the harness (with particular emphasis on the factors causing its degradation) and the conditions for its withdrawal from use. Based on the research conducted at CIOP-PIB, the problem of threats to humans in a suspended state in harness was presented.

Keywords: falls from height, harness, full body harness, work positioning belt 


\section{Wstęp}

Stosowanie indywidualnego sprzętu chroniącego przed upadkiem z wysokości jest jednym z podstawowych sposobów ochrony ludzi przed tego typu zdarzeniami - zarówno w środowisku pracy, jak i podczas uprawiania sportu i rekreacji. O skali problemu mogą świad czyć dane Głównego Urzędu Statystycznego [1], pokazujące że w 2019 r. w Polsce doszło do 5092 wypadków związanych z upadkiem z wysokości, w których zginęły 32 osoby, a 29 odniosło ciężkie obrażenia. Sytuacja ta do tyczy zwłaszcza takich branż, jak przetwórstwo przemysłowe i budownictwo. W przypadku uprawiania sportu i rekreacji sprzęt chroniący przed upadkiem z wysokości jest stosowany m.in. we wspinaczce wysokogórskiej i skałkowej oraz w speleologii.

Integralnym elementem wszystkich indywidualnych systemów chroniących przed upadkiem z wysokości [2] jest uprząż, którą zakłada na siebie użytkownik sprzętu. W zależności od rodzaju i przeznaczenia uprzęży do jej najważniejszych zadań należą:

- podtrzymanie ciała człowieka podczas po wstrzymywania spadania z wysokości [3]

- umożliwienie zajęcia podpartej pozycji pod czas pracy na wysokości [4]

- podtrzymanie ciała człowieka w zawieszeniu podczas wykonywania pracy techniką dostępu linowego (rope access) $[5,6]$

- uniemożliwienie wejścia w strefę zagrożoną rozpoczęciem spadania $[4,7]$.

Biorąc pod uwagę kluczową rolę uprzęży $w$ indywidualnym sprzęcie chroniącym przed upadkiem z wysokości, w niniejszym artykule przedstawiono ich podstawowe konstrukcje, stawiane im wymagania oraz przeznaczenie Celem prezentowanego artykułu jest dostarczenie zasadniczych informacji niezbędnych do prawidłowego doboru uprzęży oraz ich użytkowania w środowisku pracy. Informacje te są przeznaczo ne zarówno dla użytkowników indywidualnego sprzętu chroniącego przed upadkiem z wysokości jak i dla pracowników służby bhp.

\section{Przeznaczenie i konstrukcje uprzęży}

Podstawowym rodzajem uprzęży prze znaczonej do powstrzymywania spadania z wysokości w warunkach przemysłowych są pełne szelki bezpieczeństwa, spełniające wymagania PN-EN 361:2005 [3] i przeznaczo ne do utrzymywania ciała człowieka w czasie powstrzymywania spadania oraz podczas zawieszenia po powstrzymaniu spadania Podczas powstrzymywania spadania szelki bezpieczeństwa odpowiadają za prawidłowy rozkład siły udarowej na ciało użytkownika - przenoszą naciski na mniej wrażliwe części ciała, takie jak pośladki i uda. Zadaniem szelek jest również nadanie użytkownikowi prawidło wej, tj. zbliżonej do pionowej, pozycji podczas

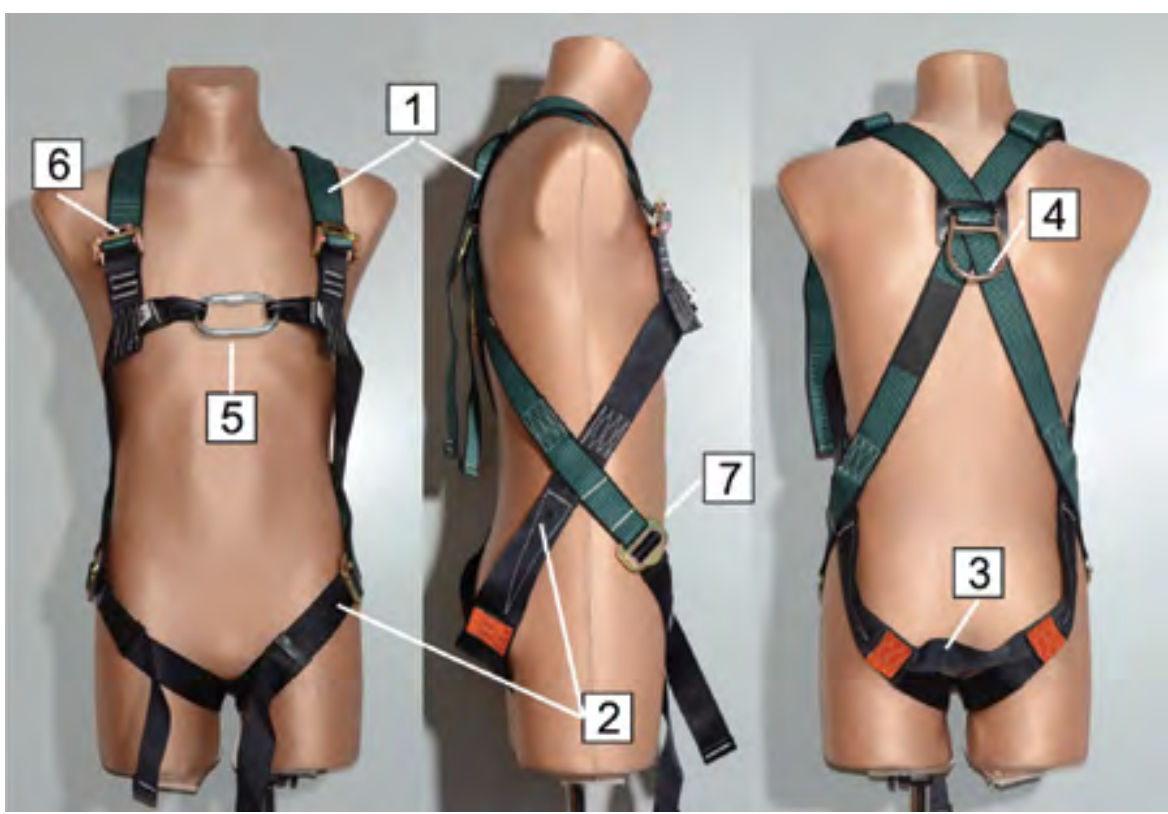

Rys. 1. Szelki bezpieczeństwa z krzyżującymi się na biodrach pasami barkowymi i udowymi: 1 - pasy barkowe, 2 - pasy udowe, 3 - siodełko, 4 - tylna klamra zaczepowa, 5 - przednia klamra zaczepowa, 6 - klamra regulacyjna pasa barkowego, 7 - klamra spinająco-regulacyjna pasa udowego

Fig. 1. Safety harness with shoulder and thigh straps crossing the hips: 1 - shoulder straps, 2 - thigh straps, 3- sit strap, 4- rear attachment buckle, 5 - front attachment buckle, 6 - adjustment buckle of the shoulder strap, 7-clamp and adjustment buckle of the thigh belt

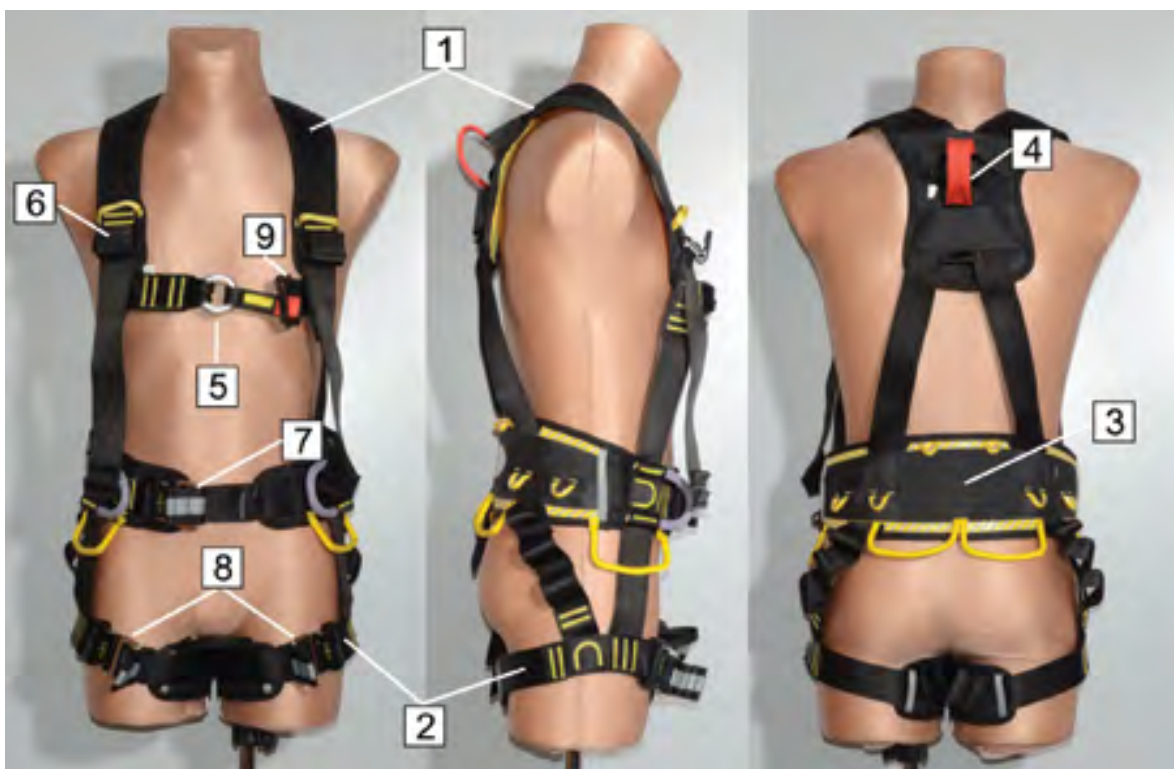

Rys. 2. Szelki bezpieczeństwa z pasami udowymi połączonymi z pasem biodrowym: 1 - pasy barkowe, 2 - pasy udowe, 3 - pas biodrowy, 4 - element zaczepowy tylny, 5 - przednia klamra zaczepowa, 6-klamra regulacyjna pasa barkowego, 7-klamra spinająco-regulacyjna pasa biodrowego, 8 - klamra spinająco-regulacyjna pasa udowego, 9 -klamra spinająca pasa piersiowego Fig. 2. Safety harness with thigh belts connected to the hip belt: 1- shoulder straps, 2 - thigh straps, 3- hip belt, 4 - rear attachment element, 5 - front attachment buckle, 6 -adjustment buckle of the shoulder strap, 7-buckle and adjustment of the hip belt, 8 - buckle and adjustment of the thigh belt, 9 - buckle of the chest belt

wiszenia po powstrzymaniu spadania, w celu umożliwienia bezpiecznego i w miarę wygodnego oczekiwania na udzielenie pomocy. Szelki bezpieczeństwa są konstrukcją składającą się z taśm włókienniczych, odpowiednio połączonych ze sobą za pomocą szwów i elementów spinających (np. klamer) - tak, że tworzą układ pasów nośnych obejmujących ciało użytkow- nika. Szelki wyposażone są w jeden lub kilka elementów zaczepowych (np. stalowych klamer), służących do przyłączania podzespołu łącząco-amortyzującego. Elementy zaczepowe przeznaczone do powstrzymywania spadania oznaczane są na szelkach bezpieczeństwa literą $A$. Najczęściej spotykane warianty konstrukcyjne tych szelek przedstawiono na rys. 1 i 2. 
W skład szelek przedstawionych na rys. 1 wchodzą pasy barkowe (1) i udowe (2), krzyżujące się na wysokości bioder użytkownika. Połączenie to umożliwia przesuwanie się pasów przy dopasowywaniu do sylwetki użytkownika. Pasy udowe pod pośladkami są połączone za pomocą tzw. siodełka (3). Szelki są wyposażone w przednią (5) i tylną (4) klamrę zaczepową, do której jest przyłączany podzespół łącząco-amortyzujący np. amortyzator [8], urządzenie samohamowne [9] lub urządzenie samozaciskowe [10]. Dopasowanie do sylwetki użytkownika zapewniają klamry spinająco-regulacyjne, umieszczone na pasach barkowych (6) oraz udowych (7).

Innym rozwiązaniem szelek bezpieczeństwa jest konstrukcja przedstawiona na rys. 2. W tym rozwiązaniu pasy udowe (2) są połączone z pasami barkowymi, trwale zamocowanymi do pasa biodrowego (3). Pasy barkowe i udowe tych szelek są wyposażone w poduszki zmniejszające nacisk taśm włókienniczych na ciało użytkownika. Pas biodrowy spełnia funkcje konstrukcyjne, a ponadto służy do nadawania pozycji podpartej podczas pracy na wysokości. Dopasowanie szelek do sylwetki użytkownika jest uzyskiwane za pomocą klamer regulacyjno-spinających (6), (7) i (8). Dwie klamry zaczepowe (4) i (5) służą do połączenia z podzespołem łącząco-amortyzującym zestawu sprzętu chroniącego przed upadkiem z wysokości.

Kolejnym rodzajem uprzęży, spełniającym wymagania PN-EN 358:2019-01 [4], są pasy bio

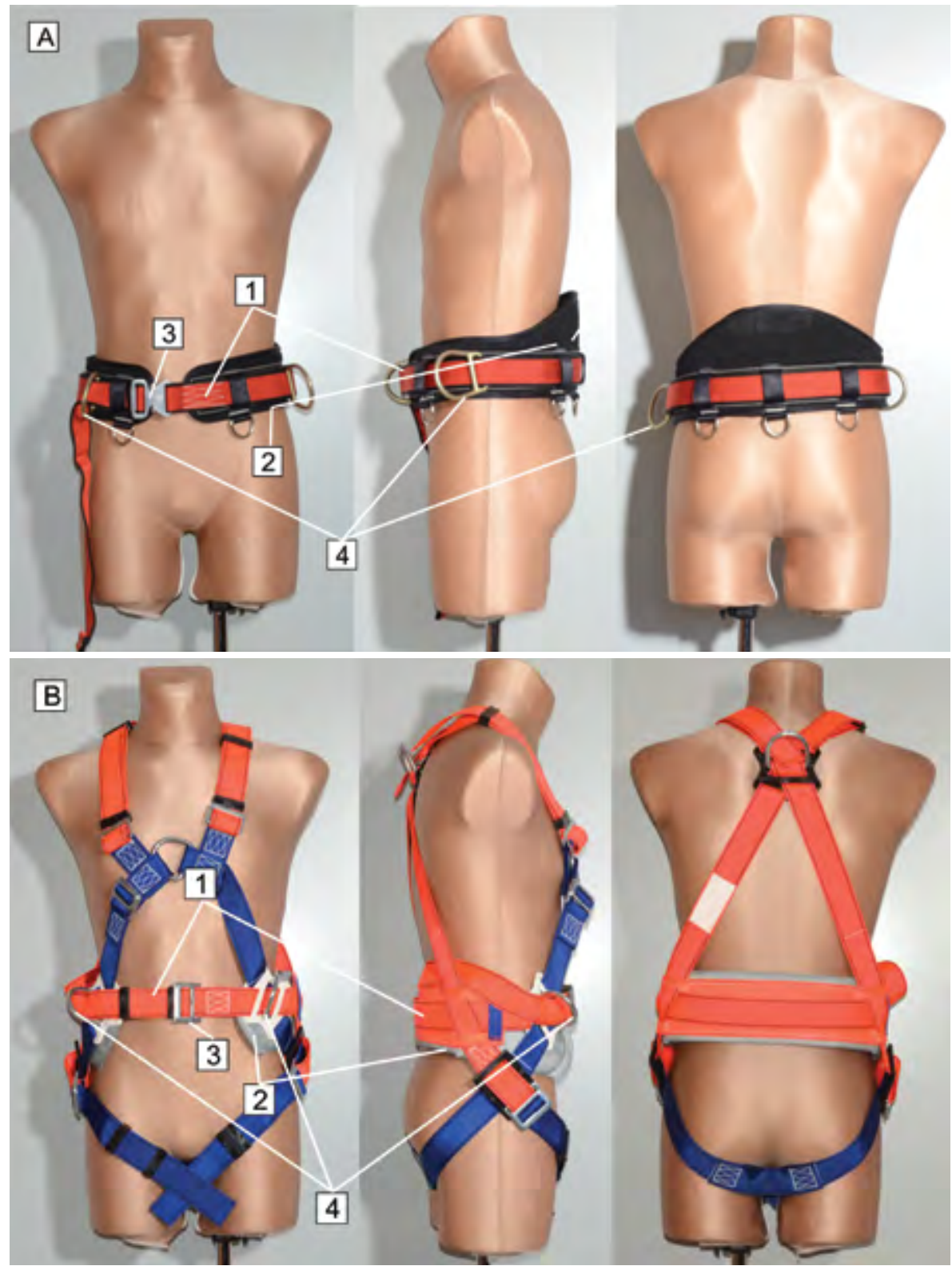

Rys. 3. Uprząż do ustalania pozycji podczas pracy na wysokości: A - uprząż niezależna, B - pas stanowiący integralną część szelek bezpieczeństwa, 1-taśma pasa biodrowego, 2-poduszka przeciwuciskowa, 3-klamra spinająco-regulacyjna, 4 - klamry zaczepowe dla linki do ustalania pozycji

Fig. 3. Harness for work positioning: A - independent work positioning belt, $B$ - belt which is an integral part of the safety har ness, 1 - waist belt strap, 2 - anti-pressure cushion, 3-adjustment buckle, 4-attachment buckles for work positioning lanyard drowe przeznaczone do ustalania pozycji podczas pracy na wysokości. Głównym zadaniem pasów pokazanych na rys. 3 jest umożliwienie zajęcia przez użytkownika podpartej pozycji podczas pracy na wysokości lub wyeliminowanie możliwości jego przemieszczania się poza bezpieczną strefę.

Takie uprzęże ze względów bezpieczeństwa nie nadają się do powstrzymywania spadania z wysokości. Podstawowa funkcja tego sprzętu jest osiągana przez dołączenie do klamer zaczepowych pasa (4) linki o regulowanej długości, która jest opasana wokół elementu konstrukcyjnego stanowiska pracy, np. słupa żerdziowego. Dzięki obciążeniu przez użytkownika pasa do tyłu, tzn. dzięki oparciu się na nim, uzyskuje się pozycję wygodną do pracy, nieangażującą rąk w celu asekuracji. Pas przedstawiony na rys. 3 może być również wykorzystany do ograniczenia przemieszczania się użytkownika do bezpiecznej dla niego strefy. W takiej sytuacji jedna z klamer zaczepowych pasa jest łączona z punktem kotwiczenia na stanowisku pracy za pomocą linki o regulowanej długości, dobranej tak, aby nie było możliwości przemieszczenia się poza bezpieczną strefę. Pas składa się z taśmy włókienniczej (1) połączonej z klamrą spinająco-regulacyjną (3), która umożliwia rozpięcie i dopasowanie pasa do sylwetki użytkownika. Pasy biodrowe są wyposażane w poduszkę przeciwuciskową (2), zmniejszającą nacisk i rozkładającą go na większą powierzchnię, podnosząc tym samym komfort użytkowania. Pasy do ustalania pozycji mogą stanowić niezależny sprzęt (rys. 3A) lub być zintegrowane z szelkami bezpieczeństwa (rys. 3B).

Sprzętem przeznaczonym do pracy na wysokości jest również uprząż biodrowa spełniająca wymagania PN-EN 813:2008 [5], której przykładowe rozwiązanie konstrukcyjne przedstawiono na rys. 4.

W zależności od konstrukcji uprząż biodrowa może być przeznaczona do uniemożliwienia rozpoczęcia spadania z wysokości, ustalania pozycji podczas pracy i pracy w podwieszeniu w technice dostępu linowego (rope access), nie nadaje się natomiast do powstrzymywania spadania z wysokości. Jedną z jej głównych cech jest lokalizacja elementu zaczepowego (4) w okolicy środka ciężkości użytkownika. Element ten jest wykorzystywany do połączenia z podzespołem umożliwiającym zawieszenie użytkownika. W skład uprzęży (rys. 4) wchodzą: pas biodrowy (1), wyposażony w boczne elementy zaczepowe (5) dla linki do ustalania pozycji, oraz pasy udowe (3) z klamrami spinająco-regulacyjnymi, pozwalającymi na dopasowanie do obwodu ud użytkownika. Dopasowanie uprzęży do sylwetki użytkownika jest osiągane dzięki klamrom spinająco-regulacyjnym (7), umieszczonym na pasie biodrowym (1). Dzięki konstrukcji uprzęży, a w tym zastosowaniu - dzięki taśmom (8) łączącym pasy udowe z biodrowym - podczas zawieszenia na elemencie zaczepowym (4) jest wymuszane podciągnięcie przodu pasów udowych do góry. W efekcie użytkownik przyjmuje pozycję zbliżoną do siedzącej. Zastosowanie poduszek przeciwuciskowych (2) 


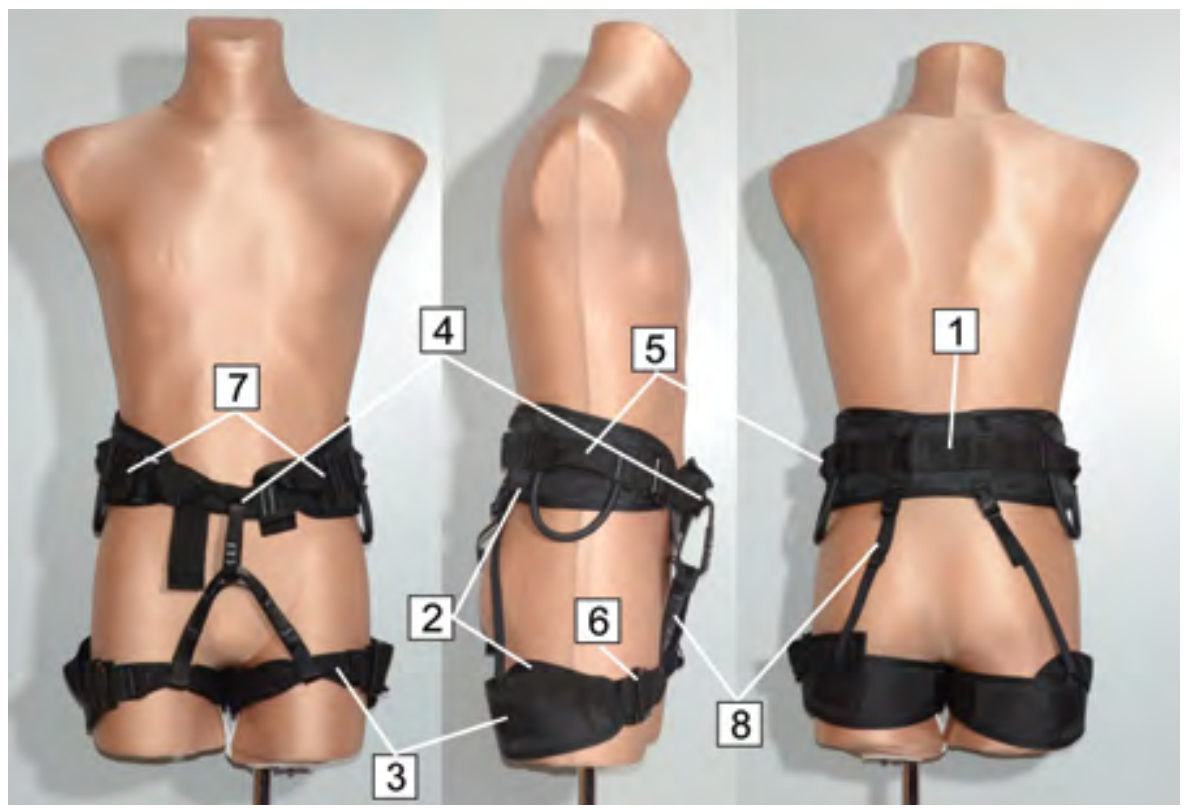

Rys. 4. Uprząż biodrowa: 1 - pas biodrowy, 2-poduszki przeciwuciskowe, 3- pas udowy, 4 - element zaczepowy pasa biodrowego 5-elementy zaczepowe dla linki do ustalania pozycji, 6-klamra spinająco-regulacyjna pasa udowego, 7-klamra spinająco-regulacyjna pasa biodrowego, 8 - taśmy łączące pas biodrowy z pasami udowymi

Fig. 4. Sit harness: 1-hip belt, 2-anti-pressure cushions, 3-thigh belt, 4- hip belt attachment element, 5-attachment elements for work positioning, 6-clamp and adjustment buckle of the thigh belt, 7-buckle and adjustment of the hip belt, 8-tapes connecting the hip belt with the thigh belts

zwiększa komfort użytkownika związany z naciskiem taśm włókienniczych na jego ciało w fazie zawieszenia.

Do uprawiania alpinizmu, w tym do wspinaczki, przeznaczone są uprzęże spełniające wymagania PN-EN 12277+A1:2019 [6] - takie uprzęże mogą więc być wykorzystywane zarówno do powstrzymywania spadania z wysokości, jak i do utrzymania użytkownika w stanie zawieszenia. Spośród uprzęży scharakteryzowanych w normie można wskazać na dwie główne konstrukcje:

- jednoczęściową (typu A), która obejmuje co najmniej górną część ciała użytkownika i jego uda

- dwuczęściową, zawierającą uprząż typu C (składającą się z pasa biodrowego i części podmiednicowej), połączoną z uprzężą typu D (obejmującą górną część ciała użytkownika i otaczającą klatkę piersiową pod pachami).

Konstrukcja uprzęży umożliwia współpracę $z$ linami alpinistycznymi.

\section{Podstawowe wymagania wobec uprzęży i stosowanych w nich materiałów}

Przedstawione informacje nt. uprzęży wskazują, że są one newralgicznym składnikiem zestawów sprzętu chroniącego przed upadkiem z wysokości, decydującym o bezpieczeństwie użytkowników, a w skrajnych przypadkach - o ich życiu. W związku z tym uprzęże przed dopusz czeniem na rynek Unii Europejskiej muszą zostać poddane badaniom sprawdzającym spełnienie wymagań zdefiniowanych w rozporządzeniu Parlamentu Europejskiego i Rady (UE) 2016/425 [11] oraz normach z nim zharmonizowanych. Najważ niejsze wymagania stawiane uprzężom dotyczą: upadkiem z wysokości jest jej prawidłowy dobór - z uwzględnieniem występujących zagrożeń, czynności wykonywanych na stanowisku pracy oraz panujących tam warunków. W pierwszej kolejności trzeba ustalić, czy występuje zagrożenie rozpoczęcia spadania. Jeżeli tak, to jedynym rozważanym rozwiązaniem powinno być zastosowanie pełnych szelek bezpieczeństwa [3], wyposażonych w przedni lub przedni i tylny zaczep. Wybór usytuowania zaczepu jest uzależniony od przewidzianego do użycia rodzaju podzespołu łącząco-amortyzującego, np. w przypadku urządzeń samozaciskowych ze sztywnymi prowadnicami preferowany jest zaczep przedni. Jeżeli na danym stanowisku przewidywane jest wykonywanie pracy w podparciu, konieczne jest użycie pasa do ustalania pozycji [4] lub szelek bezpieczeństwa wyposażonych $w$ taki pas $[3,4]$.

Prace związane z zawieszeniem pracownika, np. zastosowanie techniki dostępu linowego, wymagają użycia uprzęży spełniającej co najmniej wymagania normy PN-EN 813:2008 [5]. Głównym problemem jest jednak dobranie uprzęży, która pozwoli na zawieszenie człowieka w pozycji siedzącej bez wywierania niebezpiecznych nacisków na jego ciało.

Analiza zdarzeń wypadkowych dotyczących użycia indywidualnego sprzętu chroniącego przed upadkiem z wysokości [12-18] wskazuje na występowanie istotnego zagrożenia, związanego z zawieszeniem człowieka w uprzęży. To zagrożenie (ang. suspension trauma) może się pojawiać zarówno po powstrzymaniu spadania, jak i w sytuacji celowego zawieszenia, któremu nie towarzyszy obciążenie dynamiczne. Efektem zawieszenia mogą być naciski uprzęży na ciało użytkownika, które zakłócają oddychanie i pracę układu krwionośnego, a w konsekwencji powodują np. silny ból, drętwienie kończyn, utratę przytomności, a nawet śmierć. Przyczyny zjawiska suspension trauma leżą zarówno po stronie organizmu człowieka, jak i sprzętu, którego używa. Do najważniejszych z nich można zaliczyć budowę anatomiczną (zwłaszcza budowę klatki piersiowej), wymiary, masę ciała i stan psychofizyczny człowieka, a także działanie takich czynników, jak: przyjmowane leki, alkohol itp., kąt zawieszenia w uprzęży, ułożenie nóg, czas i bezruch w stanie zawieszenia oraz konstrukcja szelek bezpieczeństwa, w tym położenie klamry zaczepowej i dopasowanie szelek do sylwetki użytkownika. Biorąc pod uwagę możliwe negatywne skutki zawieszenia w uprzęży, użytkownik uprzęży, zwłaszcza przeznaczonej do powstrzymywania spadania, powinien pozostawać w stanie zawieszenia przez możliwie najkrótszy czas. Ma to szczególne znaczenie w przypadku, gdy człowiek traci przytomność, np. na skutek zderzenia z elementami stanowiska pracy podczas powstrzymywania spadania. Na tę okoliczność należy opracować technikę ewakuacji pracownika oraz zapewnić odpowiednie środki techniczne, aby zabezpieczyć użytkownika przed negatywnymi skutkami zawieszenia. 
W doborze uprzęży do warunków pracy bardzo istotnym zagadnieniem jest identyfikacja czynników, które mogą wpływać na utratę parametrów ochronnych. Do najważniejszych z tych czynników można zaliczyć:

- wysoką temperaturę i promieniowanie podczerwone (IR)

- promieniowanie ultrafioletowe (UV)

- rozpryski stopionego metalu

- zapylenie

- agresywne substancje chemiczne.

Stwierdzenie obecności któregoś z wymienio nych czynników powinno skutkować sprawdze niem, czy konkretna uprząż może być stosowana w warunkach jego występowania. W tym celu należy przeanalizować zapisy instrukcji użytkowania lub przeprowadzić konsultację z producentem uprzęży albo jego przedstawicielem.

Kolejnym krokiem jest dopasowanie uprzęży do sylwetki użytkownika. Przykład dopasowania szelek bezpieczeństwa do sylwetki manekina an tropomorficznego przedstawiono na rys. 5.

To dopasowanie polega na doborze odpowiedniego rozmiaru uprzęży (jeżeli jest ona produkowana w różnych rozmiarach) oraz ustawieniu klamer regulacyjnych. Regulacja klamer powinna przebiegać zgodnie z wytycznymi pro ducenta, zawartymi w instrukcji użytkowania, i ma na celu osiagnięcie odpowiedniego docisku pasów składowych uprzęży do ciała użytkownika

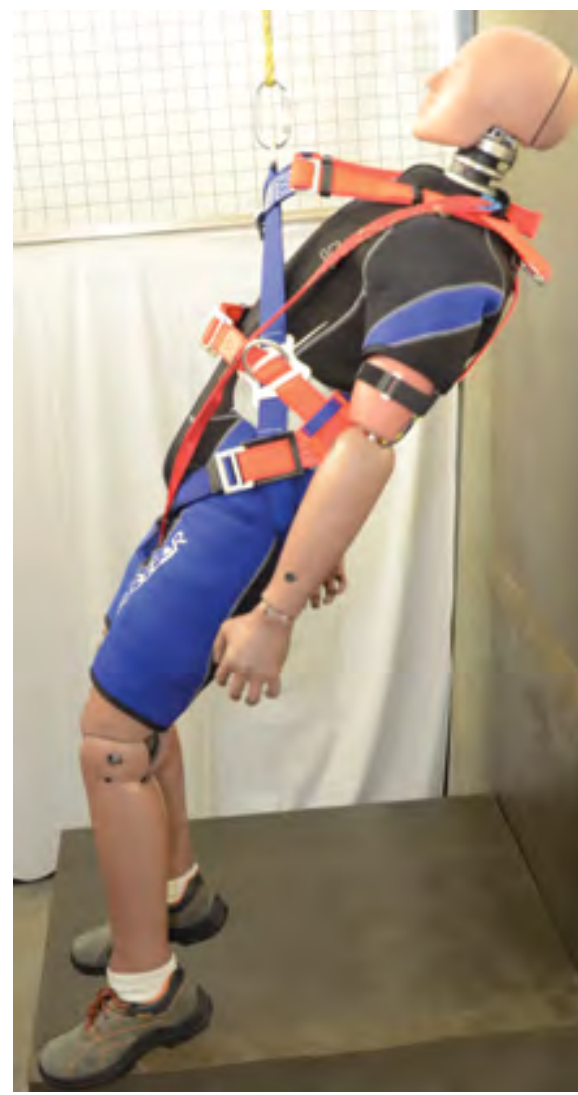

Rys. 5. Przykład układania się prawidłowo dopasowanych szelek bezpieczeństwa na manekinie antropomorficznym w stanie zawieszenia

Fig. 5. An example of a correctly fitted safety harness positioning on an anthropomorphic dummy in a suspended state oraz uzyskanie położenia klamer zaczepowych i regulacyjno-spinających. Dopasowanie uprzęży ma bezpośredni wpływ na bezpieczeństwo użytkownika, ponieważ decyduje o jego pozycji podczas i po powstrzymaniu spadania oraz o naciskach pasów i klamer. W przypadku uprzęży do pracy w podparciu i zawieszeniu dopasowanie decyduje o naciskach wywieranych na ciało człowieka w warunkach statycznych, a tym samym - o jego bezpieczeństwie i komforcie.

\section{Kontrola stanu technicznego uprzęży i warunki wycofywania z użytkowania}

Podczas użytkowania uprzęże tracą swoje właściwości ochronne. Ten proces jest uzależ niony od warunków i sposobu użytkowania. Do najbardziej destrukcyjnych czynników należą: silne obciążenia mechaniczne, zabrudzenia agresywnymi substancjami chemicznymi i pyłami, promieniowanie UV, rozpryski stopionego metalu, otwarty płomień itp. [19]. W związku z tym uprzęże podlegają okresowym kontrolom stanu technicznego, które w pierwszej kolejności powinny dotyczyć sprawdzenia, czy nie upłynął okres, w którym producent gwarantuje zachowanie właściwości ochronnych. Taką kontrolę przeprowadza się na podstawie daty wydania uprzęży do stosowania oraz zapisu w instrukcji użytkowania uprzęży. W praktyce okres użytkowania uprzęży wykonanych z taśm poliamidowych lub poliestrowych najczęściej wynosi pięć lat. Okresowe sprawdzanie stanu technicznego uprzęży powinno być prowadzone przez kompetentną osobę, np. u producenta, w jego autoryzowanym serwisie, lub przez odpowiednio przeszkolonego pracownika. Kontrola powinna dotyczyć zarówno elementów włókienniczych i metalowych, jak i elementów z tworzyw sztucznych. Przykłady uszkodzeń, które wymagają wycofania uprzęży $z$ użytkowania, przedstawiono w artykule [20].

Uprząż należy wycofać z użytkowania $w$ trzech podstawowych przypadkach, tj. gdy: uległa silnemu obciążeniu, zidentyfikowano dyskwalifikujące ją uszkodzenia, upłynął okres (określony przez producenta), w którym może być stosowana. Co ważne, uprząż, która uległa silnemu obciążeniu mechanicznemu na skutek powstrzymania spadania, należy wycofać z użytkowania niezależnie od tego, czy nosi ślady widocznych uszkodzeń, czy nie.

\section{Podsumowanie}

W artykule wskazano na dużą różnorodność konstrukcji uprzęży stosowanych zarówno na stanowiskach pracy na wysokości, jak i podczas uprawiania sportu czy rekreacji. Ta różnorodność wiąże się z funkcjami i warunkami stosowania uprzęży, a tym samym z koniecznością dokonania prawidłowego wyboru, który decyduje o bezpieczeństwie i komforcie użytkowania. Warunkiem bezpiecznego stosowania uprzęży jest również jej prawidłowe dopasowanie do sylwetki użytkownika. Osiąga się to zarówno przez dobór odpo- wiedniego rozmiaru uprzęży, jak i przez regulację klamer spinająco-regulacyjnych.

Stosując uprzęże, należy pamiętać również o specyficznych zagrożeniach, wynikających $z$ ich działania na ciało użytkownika. Te zagrożenia są związane z powstrzymywaniem spadania z wysokości, gdy na ciało człowieka oddziałują dynamicznie pasy i metalowe klamry, zwłaszcza w przypadku nieprawidłowego dopasowania uprzęży do sylwetki użytkownika. Drugim istotnym zagrożeniem jest działanie uprzęży w warunkach statycznych w stanie zawieszenia, np. po powstrzymaniu spadania lub podczas pracy w zawieszeniu. Towarzyszą temu m.in. zakłócenia działania układu krwionośnego człowieka, utrudnienie oddychania i ucisk na organy wewnętrzne. $Z$ tego powodu po powstrzymaniu spadania człowiek powinien być ewakuowany w możliwie najkrótszym czasie, zwłaszcza w sytuacji, gdy doszło do utraty przytomności.

Użytkowanie uprzęży w warunkach działania różnych niekorzystnych czynników środowiskowych, np. zanieczyszczeń pyłowych, rozprysków stopionego metalu czy agresywnych substancji chemicznych, oraz w sytuacji wystąpienia uszkodzeń wynikających z wykonywanych czynności, np. przecięć przez ostre elementy stanowiska pracy, powoduje utratę jej właściwości ochronnych. Z tego względu bardzo istotne jest kontrolowanie stanu technicznego uprzęży i wycofanie jej z użytkowania, gdy przestaje spełniać swoją rolę i zagraża bezpieczeństwu użytkownika.

\section{BIBLIOGRAFIA}

[1] Główny Urząd Statystyczny (GUS). Wypadki przy pracy w 2019 roku. Warszawa, Gdańsk 2020.

[2] SULOWSKI, A.C. Fall arresting systems - classification. [In:] A.C. Sulowski (ed.), Fundamentals of fall protection. Toronto (Canada): International Society for Fall Protection 1991, pp. 285-301.

[3] PN-EN 361:2005. Środki ochrony indywidualnej chroniące przed upadkiem z wysokości - Szelki bezpieczeństwa.

[4] PN-EN 358:2019-01. Środki ochrony indywidualnej do ustalania pozycji podczas pracy i zapobiegania upadkom z wysokości - Pasy i linki bezpieczeństwa do ustalania pozycji podczas pracy lub ograniczania przemieszczania.

[5] PN-EN 813:2008. Indywidualny sprzęt chroniący przed upadkiem z wysokości - Uprząż biodrowa.

[6] PN-EN 12277+A1:2019. Sprzęt alpinistyczny Uprzęże - Wymagania bezpieczeństwa i metody badań.

[7] PN-EN 363:2019-01. Środki ochrony indywidualnej przed upadkiem z wysokości- Indywidualne systemy chroniące przed upadkiem z wysokości.

[8] PN-EN 355:2005. Środki ochrony indywidualnej chroniące przed upadkiem z wysokości - Amortyzatory.

[9] PN-EN 360: 2005. Środki ochrony indywidualnej chroniące przed upadkiem z wysokości - Urządzenia samohamowne. 
[10] PN-EN 353-2:2005. Środki ochrony indywi dualnej chroniące przed upadkiem z wysokości - Część 2: Urządzenia samozaciskowe z giętką prowadnicą.

[11] Rozporządzenie Parlamentu Europejskiego i Rady (UE) 2016/425 z dnia 9 marca 2016 r. w sprawie środków ochrony indywidualnej oraz uchylenia dyrektywy Rady 89/686/EWG (Dz.Urz. L81 z 31.03.2016 r., s. 51).

[12] HEARON, B.F., BRINKLEY, J.W. Fall arrest and post-fall suspension: literature review and directions for further research. [In:] A.C. Sulowski (ed.) Fundamentals of fall protection. Toronto, Ontario (Canada): International Society for Fall Protection. [13] BARIOD, J., THERY, B. On the pathology introduced by the harness. Spelunca. 1994, 55.

[14] SEDDON, P. Harness suspension: review and evaluation of existing information. Health and Safety Executive. Contract Research Report 451/2002.
[15] ORZECH, M.A., et al. Test program to evaluate human response to prolonged motionless suspension in three types of fall protection harnesses. Harry G. Armstrong Aerospace Medical Research Laboratory. Wright Patterson Air Force Base. USA 1987.

[16] BARIOD, J., THERY, B. Medizinische Auswirkungen des Hängens in Sicherheitsgurten (The medical effects of being suspended in safety harnesses). BG (Magazine). Germany 1997.

[17] WEBER, P., MICHELS-BRENDAEL, G. Physiologie beanspruchungen beim hägen in Auffanggurten (Physiological limits of suspension in harnesses). Germany: Johann Wolfgang Goethe University, 1990.

[18] LIEBLICH, M., RENSING, W. Rettung von Abgestürzten und Erste Hilfe nach Hängen im Gurt (Rescuing people who have fallen and first aid following suspension in a safety harness). ASvorORT (Magazine). 1997, 1: 12.
[19] BASZCZYŃSKI, K., JACHOWICZ, M. The effect of the use of full body harnesses on their protective properties. JOSE, 2019. 15(4): 435-446.

[20] BASZCZYŃSKI, K. Sprawdzanie stanu technicznego uprzęży w indywidualnych systemach chroniących przed upadkiem z wysokości. Bezpieczeństwo Pracy. Nauka i Praktyka. 2013, 10: 27-30.

Opracowano i wydano na podstawie wyników V etapu programu wieloletniego "Poprawa bezpieczeństwa i warunków pracy", finansowanego w zakresie badań naukowych i prac rozwojowych ze środków Narodowego Centrum Badań i Rozwoju (projekt nr III.PB.16 pt. "Opracowanie szelek bezpieczeństwa umożliwiajacych bezpieczne oczekiwanie na pomoc po powstrzymaniu spadania"). Koordynator programu: Centralny Instytut Ochrony Pracy - Państwowy Instytut Badawczy. 